Індивідуальна траєкторія професійної адаптації студентів-військовослужбовців (учасників бойових дій) до продуктивної діяльності у сфері послуг

УДК 370.89.56

\title{
ІНДИВІДУАЛЬНА ТРАСКТОРІЯ ПРОФЕСІЙНОЇ АДАПТАЦЇ̈ СТУДЕНТІВ-ВІЙСЬКОВОСЛУЖБОВЦІВ (УЧАСНИКІВ БОЙОВИХ ДІЙ) ДО ПРОДУКТИВНОЇ ДІЯЛЬНОСТІ У СФЕРІ ПОСЛУГ
}

\author{
Світлана Зінченко \\ директор Нікопольського регіонального Центру \\ моніторингу освіти та соціального партнерства \\ ORCID ID 0000-0003-1242-2414 \\ svzi@ukr.net
}

\begin{abstract}
Анотація. У статі теоретично обгрунтовано індивідуальну траєкторію, що сприяє оптимізації та ефективності професійної адаптації студентів-військовослужбовців до продуктивної діяльності у сфері послуг; розроблено та експериментально апробовано методику формування професійної адаптації студентів-військовослужбовців до продуктивної діяльності у сфері послуг. Визначено поняття «індивідуальна траєкторія», «індивідуальний маршрут» професійної адаптації студентів-військовослужбовців (учасників бойових дій). Розроблено критерії професійної адаптації студентів-військовослужбовців. 3'ясовано, що індивідуальна освітня траєкторія - це рух до досягнення рівня професійної компетентності, що здійснюється за постійної педагогічної підтримки і контролю, під час якого відбувається творча самореалізація, прояв і розвиток особистісних якостей. Індивідуальний освітній маршрут - це персональна програма для ефективної професійної адаптації фахівця, що відповідає його віку і здібностям, інтересам, мотивації, яка спроєктована на базі освітньопрофесійної програми.
\end{abstract}

Ключові слова: професійна адаптація; продуктивна діяльність; інтерактивні технології; студенти-військовослужбовці; індивідуальна траєкторія.

Постановка проблеми. Одним із суттєвих чинників покращення професійної та соціально-психологічної адаптації студентіввійськовослужбовців (учасників бойових дій) до продуктивної діяльності у сфері послуг є навчання, підвищення ефективності якого можна забезпечити шляхом упровадження в навчально-виховний процес інтерактивних методів навчання та виховання, сучасних комп'ютерних технологій з урахуванням педагогічних умов професійної адаптації.

У наш час існує багато даних про вплив умов навчання на продуктивну діяльність і психологічний стан студента-військовослужбовця. Сучасні умови продуктивної діяльності у сфері послуг висувають підвищенні вимоги до професійної адаптації студентів-військовослужбовців (учасників бойових дій), тому це питання необхідно розглядати 3 усіх аспектів: педагогічного, соціального, психологічного, навчального, професійного тощо.

Недостатнє навчально-методичне та наукове забезпечення індивідуальної траєкторії навчання, практичне розроблення з професійної адаптації студентів-

Професіоналізм педагога: теоретичні й методичні аспекти. - Вип. 12. - Слов'янськ, 2020. 
Індивідуальна траєкторія професійної адаптації студентів-військовослужбовців (учасників бойових дій) до продуктивної діяльності у сфері послуг

військовослужбовців (учасників бойових дій) до продуктивної діяльності у сфері послуг, актуальність і необхідність оптимізації педагогічних умов адаптації зумовили необхідність наукового обгрунтування цього питання.

Аналіз останніх досліджень і публікацій. За аналізом психологопедагогічної, філософської літератури, станом вивченості явища «професійна адаптація» серед учених необхідно відзначити таких, як В. Андреєв, І. Бондар, В. Дем'янишин, А. Крупник, С. Прилипко, Г. Чанишева та ін. Найчастіше поняття «професійна адаптація» вживається в педагогіці, психології, соціології. У педагогіці проблему адаптації досліджували О. Мороз (1984), Є. Савченко (2018) та ін. У своїх дослідженнях вони розглядали педагогічний аспект адаптації, що передбачає визначення комплексу методів педагогічного впливу на особистість. У педагогічному дослідженні Л. Ростової (1973) «адаптація» визначається як пристосування та звикання до нових умов праці, до нової обстановки, нового соціального оточення та норм його поведінки, нового предметного змісту навчальної та трудової діяльності.

Поняття «педагогічні умови» стало предметом дослідження таких учених, як В. Жернов, 3. Курлянд, В. Стасюк та ін. У довіднику з професійної педагогіки поняття «педагогічні умови» визначається як «обставини, від яких залежить цілісний продуктивний педагогічний процес професійної підготовки фахівців, що опосередковується активністю особистості, групою людей» (Словникдовідник $з$ професійної педагогіки, 2006). Дослідник Л. Байбекова визначає «педагогічні умови» як цілеспрямовано створені в освітньому просторі обставини у взаємодії педагогічних, психологічних і соціально-економічних чинників, якими обумовлюється цілісний продуктивний педагогічний процес адаптації студентів до професійної діяльності, як динамічний регулятор інформаційних, особистісних, психологічних і педагогічних факторів навчання (Байбекова, 2016). В останні роки проблемні питання, які пов'язані з адаптацією особистості, розглядали у своїх працях дослідники О.Сафін (адаптація військовослужбовців до службової діяльності), В. Кислий (адаптація офіцеріввипускників до діяльності в особливих умовах), Н. Агаєв (адаптація військовослужбовців миротворчого контингенту до діяльності в особливих умовах), О. Числицька (адаптація до професійної діяльності військовослужбовців в особливих умовах) та ін.

Проблема професійної адаптації студентів-військовослужбовців до продуктивної діяльності у сфері послуг на сучасному етапі посідає важливе місце серед проблем виховання і навчання, що є суттєвими для педагогіки.

() ДВНЗ «Донбаський державний педагогічний університет» 
Індивідуальна траєкторія професійної адаптації студентів-військовослужбовців (учасників бойових дій) до продуктивної діяльності у сфері послуг

Мета статті - теоретично обгрунтувати, дослідити, визначити траєкторію, що сприяє оптимізації та ефективності професійної адаптації студентіввійськовослужбовців до продуктивної діяльності у сфері послуг; розробити та експериментально апробувати методику формування професійної адаптації студентів-військовослужбовців до продуктивної діяльності у сфері послуг.

Завдання дослідження: 1) визначити поняття «індивідуальна траєкторія», «індивідуальний маршрут» професійної адаптації студентів військовослужбовців (учасників бойових дій); 2) розробити критерії професійної адаптації студентів-військовослужбовців.

Методи дослідження: 1) теоретичні: аналіз, узагальнення і синтез наукової і методичної літератури за окресленою проблемою; 2) практичні: тестування, анкетування, метод спостереження.

База дослідження. Апробація професійної адаптації студентіввійськовослужбовців до продуктивної діяльності у сфері послуг здійснювалася на Нікопольському факультеті Національної металургійної академії України впродовж 2016 - 2019 років, у дослідженні брали участь студенти-учасники бойових дій (220 осіб), професорсько-викладацький склад, представники підприємств Нікопольського регіону Дніпропетровської області (усього 110 осіб).

Виклад основного матеріалу. Проблема професійної адаптації виникла та існує повсюди: в освіті, науці, на виробництві, в армії, тобто проблема має масштабний характер. Професійна адаптація студентів-військовослужбовців до продуктивної діяльності у сфері послуг має багатопрофільний характер. Вона складається з комплексу структурних елементів, які взаємодіють між собою. Філософи-екзистенціалісти стверджували, що буття людини завжди спроєктовано в майбутнє, пов'язане 3 необхідністю вибирати між різними проєктами майбутнього. Екзистенція адаптації як процес має низку екзистенційних характеристик, зокрема темпоральності як умови «можливої можливості» (за Н. Аббаньяно); як проєкту (за М. Гайдеггером), який осмислюється як «направленість на...», тобто екзистенція динамічна; передбачає наявність «невідчужуваного начала» (за Г. Марселем). Прогресивне положення автора трактату «Буття і час» М. Гайдеггера про те, що людина сама творить, розвиває свою сутність. М. Гайдеггер робить висновок, що сутність, зміст людського буття знаходиться у сфері волі, сфері вільного ризику і власної відповідальності за свої дії (Гайдеггер, 1997).

У зв’язку з цим заслуговує на увагу досвід Нікопольського регіонального Центру моніторингу освіти та соціального партнерства НМетАУ, який 
Індивідуальна траєкторія професійної адаптації студентів-військовослужбовців (учасників бойових дій) до продуктивної діяльності у сфері послуг

проводить четвертий рік роботу із залучення учасників бойових дій до навчання на Нікопольському факультеті НМетАУ. На сьогодні на Нікопольському факультеті НМетАУ навчається більше 220 студентів-військовослужбовців (учасників бойових дій). На нашу думку, професійна адаптація студентіввійськовослужбовців до продуктивної діяльності у сфері послуг - це складний педагогічний процес подолання адаптаційних труднощів, постійного одержання нових професійних знаній, умінь і навичок.

Відсутність ефективного формування професійної адаптації приводить до того, що студент-військовослужбовець (учасник бойових дій) не ставить мети професійного розвитку, відповідно не домагається її досягнення, і в результаті, не знає, де він опиниться в мирному житті.

Як правило, можна виділити дві типові задачі, які розв'язуються в процесі формування професійної адаптації:

1. Вибір індивідуальної траєкторії з професійної адаптації.

2. Вибір дій, за допомогою яких треба реалізувати вибрану індивідуальну програму з професійної адаптації.

При виборі і забезпеченні досягнення професійної програми на початкових етапах професійної адаптації студенту важко розібратися 3 можливостями i загрозами зовнішнього середовища, а також зі своїми сильними та слабкими сторонами.

Завданнями планування траєкторії професійної адаптації студентіввійськовослужбовців є:

1) вивчити, розвити шляхи професійної адаптації студентіввійськовослужбовців, які повинні відповідати сучасним вимогам у сфері послуг;

2) формування критеріїв професійної адаптації;

3) визначення потенціалу професійної адаптації студентіввійськовослужбовців.

Професійна адаптація студентів-військовослужбовців до продуктивної діяльності повинна базуватися на принципах (Полянська, 2013):

1) участь у розробці індивідуальних програм із професійної адаптації студентів-військовослужбовців до продуктивної діяльності;

2) коректування індивідуальної програми залежно від умов;

3) неперервність планування процесу професійної адаптації.

Планування професійної адаптації можна рекомендувати в три етапи:

1) підготовчий - оцінка знань, умінь i навичок фундаментальних дисциплін, фізичний та психологічний стан студента, уміння працювати в команді, складання індивідуальної програми з професійної адаптації; 


\section{С. ЗІНЧЕНКО}

Індивідуальна траєкторія професійної адаптації студентів-військовослужбовців (учасників бойових дій) до продуктивної діяльності у сфері послуг

2) основний (розробка курсу професійної адаптації) - проведення заходів зі студентами (додаткові навчальні заняття, консультації, тренінги, вечори професійного напрямку, тематичні екскурсії, зустрічі з провідними фахівцями тощо), закінчення індивідуальної програми;

3) завершальний етап - аналіз і узагальнення результатів професійної адаптації.

Основою для складання індивідуальної траєкторії з професійної адаптації студентів-військовослужбовців $\epsilon$ наявність показників, які характеризують навчальну, виробничу, наукову діяльність, участь у житті групи і курсу, психологічний стан, поведінка, любов до обраної професії.

На основній стадії (розробка курсу професійної адаптації) використовується інструмент планування - траєкторія професійної адаптації. Траєкторія професійної адаптації - це позиції (курси), у яких студентвійськовослужбовець буде находитися під час навчання у вищому навчальному закладі.

Професійна адаптація студента-військовослужбовця подібна руху на довгу дистанцію за складним маршрутом. Самоорганізація студентавійськовослужбовця виявляється в постійному формуванні, коректуванні професійної адаптації. Кожному студенту-військовослужбовцю пропонується скласти конкретну індивідуальну програму з професійної адаптації, яка б відповідала на запитання: де і ким він планує працювати у визначений період часу.

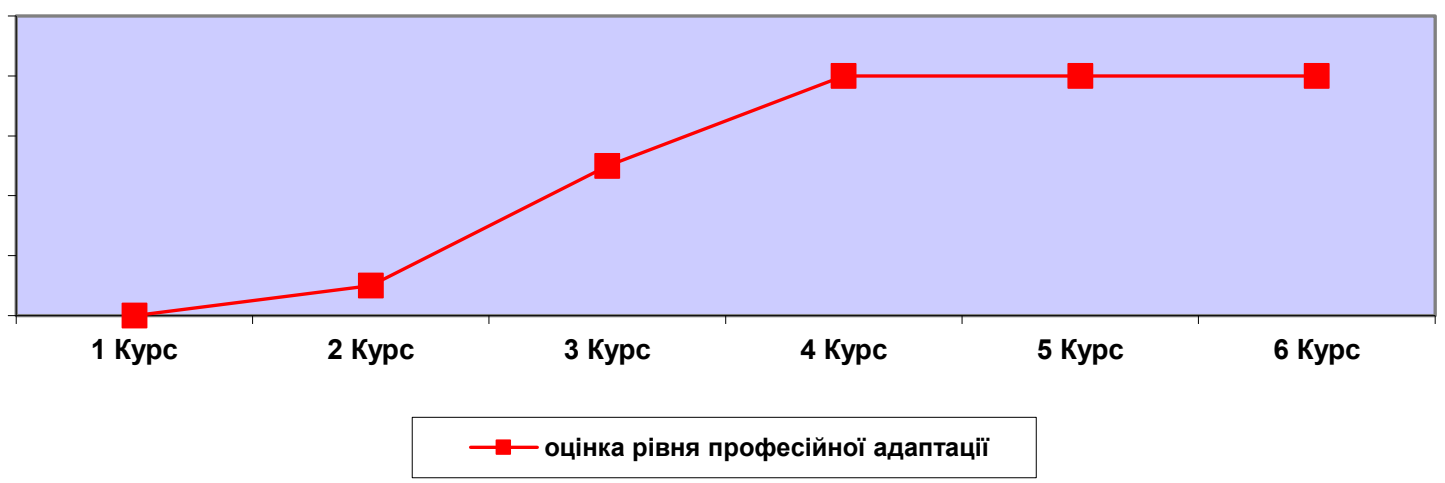

Рис. 1. Графік процесу формування професійної адаптаиії

Склавши програму (точка в багатовимірному просторі), студентвійськовослужбовець послідовно досягає виконання поставленої програми. На практиці цей процес виглядає складнішим. На різних етапах професійної адаптації студент-військовослужбовець постійно відповідає на такі запитання:

1. Куди треба рухатися? (вибір мети). 


\section{С. ЗІНЧЕНКО}

Індивідуальна траєкторія професійної адаптації студентів-військовослужбовців (учасників бойових дій) до продуктивної діяльності у сфері послуг

2. Як краще здійснити цей рух? (яким чином треба досягнути поставленої мети).

Професійна адаптація студента-військовослужбовця здійснюється впродовж навчання у вищі, у майбутньому (у перші два роки після закінчення ВНЗ) індивідуальна програма професійної адаптації повинна бути скоригована з урахуванням вимог роботодавців.

Індивідуальна траєкторія 3 професійної адаптації студентіввійськовослужбовців складається з таких питань:

1) загальні відомості про студента-військовослужбовця: прізвище, ім'я, по батькові, дата народження, військове звання, нагороди (відзнаки), освіта, поранення, сімейний стан, труднощі в навчанні, побажання (тематичні екскурсіі), мета в житті тощо;

2) схема виконання професійної адаптації (поглиблене вивчення спеціальних дисциплін, інтерактивних технологій, сучасних комп'ютерних програм тощо).

Для успішної реалізації індивідуальної траєкторії професійної адаптації студентів-військовослужбовців до продуктивної діяльності з боку студентівучасників бойових дій повинні бути здійснені:

1) успішне та якісне виконання заходів індивідуальної траєкторії 3 професійної адаптації;

2) уміння не лише використовувати професійні знання та навички, але й демонструвати нестандартні форми розв'язування виробничих задач;

3) уміння працювати в команді.

Управління процесом професійної адаптації допомагає діагностувати професійну адаптацію студента-військовослужбовця до продуктивної діяльності у сфері послуг, що дуже важливо для роботодавців, та в майбутньому професійному рості, конкурентоспроможності студента-військовослужбовця. Тільки від студента-військовослужбовця, навчального закладу і підприємства залежить професійна адаптація учасника бойових дій до продуктивної діяльності у сфері послуг. Студент-військовослужбовець самостійно дає оцінку своєї професійної адаптації, визначає, які знання і вміння необхідно йому досягти.

Ми пропонуємо використовувати при розв'язуванні задач щодо формування та оптимізації професійної адаптації студентіввійськовослужбовців методи, які використовуються в маркетингу та менеджменті.

На перших етапах формування професійної адаптації дослідники в області менеджменту стверджують, що правильний вибір, зроблений на початкових 


\section{С. ЗІНЧЕНКО}

Індивідуальна траєкторія професійної адаптації студентів-військовослужбовців (учасників бойових дій) до продуктивної діяльності у сфері послуг

етапах, дозволяє одержати максимальний успіх у продуктивній діяльності у сфері послуг.

Формуючи професійну адаптацію студента-військовослужбовця необхідно:

1) визначити можливості студента-військовослужбовця (знання, уміння, слабості характеру тощо);

2) дослідити ринок праці (Садовський, Петренко, 2009).

Професійна адаптація студентів-військовослужбовців до продуктивної діяльності у сфері послуг залежить від багатьох факторів, серед яких $\epsilon$ як суб’єктивні (які залежать від студента-військовослужбовця), так і об'єктивні.

Для ефективності та оптимізації професійної адаптації студентіввійськовослужбовців необхідно вдосконалити процес формування професійної програми за допомогою маркетингової технології вибору мети SMART. Авторство цієї технології пов'язано з ім'ям видатного дослідника в областях маркетингу та менеджменту Пітера Друкера (Вудкок, Френсіс, 1991).

Програма $з$ професійної адаптації складається з таких принципів:

- конкретність (specific) - програма повинна бути конкретною, дії студента-військовослужбовця по виконанні цієї програми сконцентровані на результат;

- вимірність (measurable) - можливість оцінки ступеня наближення досягнутого результату до програми;

- досяжність(achievable) - чи можна здійснити виконання програми;

- релевантність (relevant) - виконання цієї програми повинно наблизити студента-військовослужбовця до виконання рішень більш високих рівнів;

- визначеність у часі (timed) - програма повинна бути чітко визначеною в часі, коли студент-військовослужбовець одержить результат;

- реалістичність (realistic) - програма повинна відповідати ресурсам студента-військовослужбовця.

Розглянемо чотири варіантів програм з професійної адаптації.

Приклад 1. Студент-військовослужбовець Б. 27 р. (спеціальність: «обробка металів тиском») хоче через п'ять років бути інженером на трубному заводі.

Приклад 2. Студент-військовослужбовець П. 32 p. (спеціальність: «економіка підприємств») хоче працювати зав. відділу в банку.

Приклад 3. Студент-військовослужбовець К. 37 р. (спеціальність: «інженер-механік») хоче бути директор СТО м. Нікополь.

Приклад 4. Студент-військовослужбовець Т. 42 р. (спеціальність: «прикладна механіка») хоче мати фірму з ремонту побутової техніки. 


\section{С. ЗІНЧЕНКО}

Індивідуальна траєкторія професійної адаптації студентів-військовослужбовців (учасників бойових дій) до продуктивної діяльності у сфері послуг

Під час проведення навчальних занять і консультацій за допомогою технології SMART можна здійснити первісну «грубу» оцінку програм, які запропоновані студентам-військовослужбовцям. У таблиці 1 позначені ті варіанти програм з професійної адаптації, які можуть бути відразу «відкинуті» за одним або декількома критеріями. Після «грубого» відбору тільки 134 варіантів залишився для подальшого розгляду, а останні повинні бути відкоректовані.

Таблиия 1

«Груба» оцінка множини індивідуальних програм з професійної адаптації

\begin{tabular}{|c|c|c|c|c|c|c|c|}
\hline \multirow{2}{*}{ 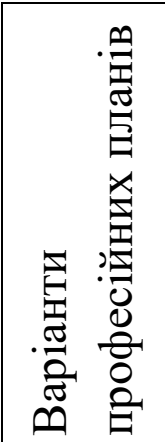 } & \multicolumn{7}{|c|}{ «Груба» оцінка (модифікація SMART) } \\
\hline & 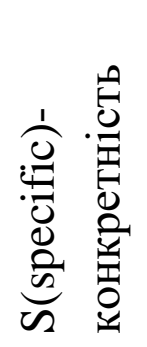 & 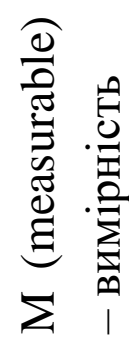 & 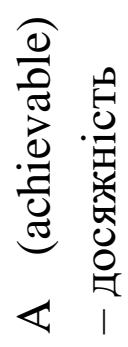 & 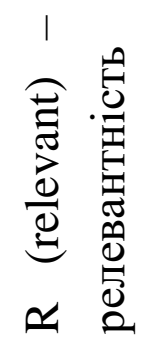 & 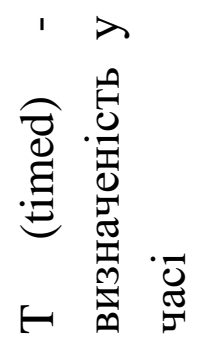 & 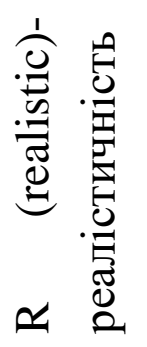 & 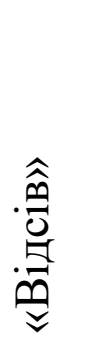 \\
\hline 1 & + & + & + & + & + & + & + \\
\hline 2 & + & - & - & + & - & - & - \\
\hline 3 & + & - & + & + & - & + & - \\
\hline 4 & + & - & + & + & - & + & - \\
\hline
\end{tabular}

Для одержання більш точної оцінки якості різноманітних варіантів індивідуальних програм із професійної адаптації можна використовувати комплексну оцінку варіантів із застосуванням вищевказаних критеріїв.

Припустимо, що значимість кожного із критеріїв різноманітна. Для оцінки значимості використовуємо невід'ємні вагові коефіцієнти $b_{1}, \ldots b_{6}$, сума яких = 1. Водночас чим більший ваговий коефіцієнт, тим більше значення має відповідний критерій. Вагові коефіцієнти є єдиними для всіх варіантів програм із професійної адаптації.

Такі вагові коефіцієнти можуть бути одержані різноманітними методами, наприклад, на основі експертних оцінок для характеристики значимості критеріїв.

Припустимо, що:

$b_{1}=0,12, b_{2}=0,1, b_{3}=0,3, b_{4}=0,25, b_{5}=0,13, b_{6}=0,1$

Кожна із множини індивідуальних програм із професійної адаптації - $\mathrm{x}$, можна оцінити на відповідність кожному з шести вказаних критеріїв вектором $\mathrm{Q}(\mathrm{x})$. 


\section{С. ЗІНЧЕНКО}

Індивідуальна траєкторія професійної адаптації студентів-військовослужбовців (учасників бойових дій) до продуктивної діяльності у сфері послуг

Ступінь відповідності може змінюватися від 0 до 10, де 0 відповідає мінімальному ступеню відповідності, а 10 - максимальному ступеню відповідності.

Підраховану зважену суму можна обчислити за формулою (Садовський, Петренко, 2009):

$$
W(x)=\sum_{i=1}^{6} b_{i} Q_{i}(x)
$$

Ми одержали комплексну оцінку цього варіанта, і зможемо порівняти 3 іншими.

Таблиия 2

Комплексна оцінка множини індивідуальних програм із професійної адаптації

\begin{tabular}{|c|c|c|c|c|c|c|c|c|c|c|c|c|c|}
\hline \multirow{3}{*}{ 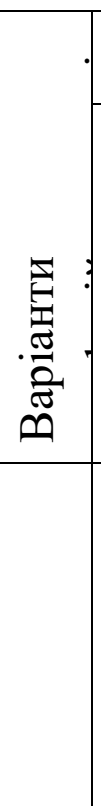 } & \multicolumn{13}{|c|}{ Комплексна оцінка (модифікація SMART) } \\
\hline & \multicolumn{2}{|c|}{ 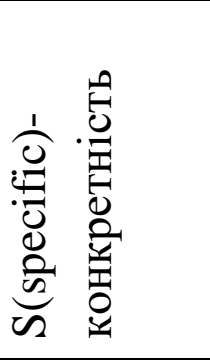 } & \multicolumn{2}{|c|}{ 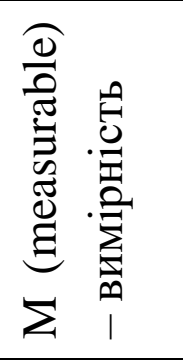 } & \multicolumn{2}{|c|}{ 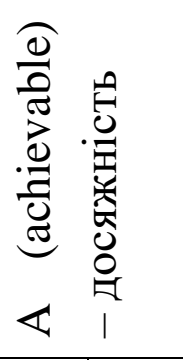 } & \multicolumn{2}{|c|}{ 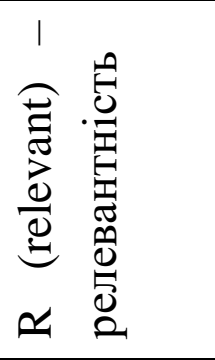 } & \multicolumn{2}{|c|}{ 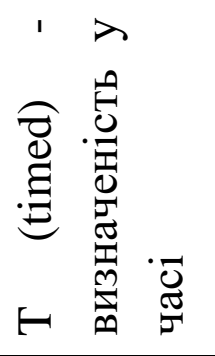 } & \multicolumn{2}{|c|}{ 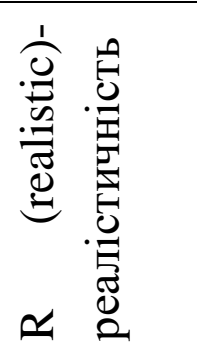 } & \multirow[t]{2}{*}{ 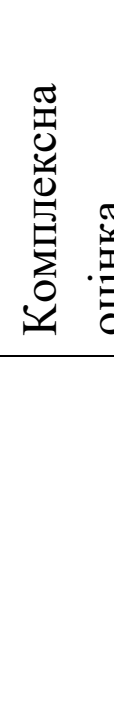 } \\
\hline & 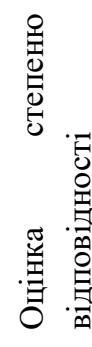 & 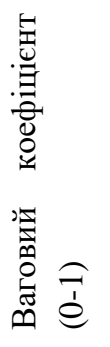 & 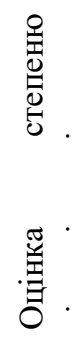 & 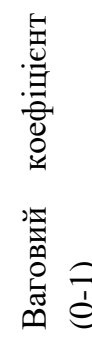 & 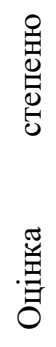 & 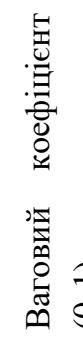 & 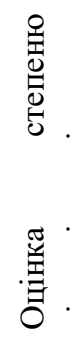 & 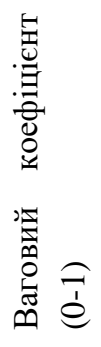 & 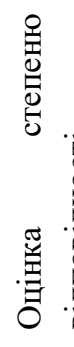 & 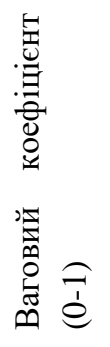 & 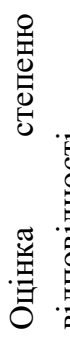 & 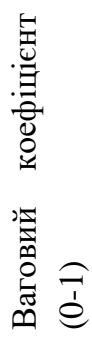 & \\
\hline 1 & 8 & 0,12 & 5 & 0,1 & 1 & 0,3 & 1 & 0,25 & 1 & 0,13 & 5 & 0,1 & 2,6 \\
\hline 2 & 3 & 0,12 & 1 & 0,1 & 5 & 0,3 & 1 & 0,25 & 1 & 0,13 & 1 & 0,1 & 2,4 \\
\hline 3 & 4 & 0,12 & 1 & 0,1 & 1 & 0,3 & 5 & 0,25 & 5 & 0,13 & 1 & 0,1 & 2,9 \\
\hline 4 & 5 & 0,12 & 5 & 0,1 & 1 & 0,3 & 9 & 0,25 & 9 & 0,13 & 5 & 0,1 & 5,3 \\
\hline 5 & 1 & 0,12 & 9 & 0,1 & 5 & 0,3 & 6 & 0,25 & 6 & 0,13 & 5 & 0,1 & 5,3 \\
\hline 6 & 1 & 0,12 & 6 & 0,1 & 9 & 0,3 & 7 & 0,25 & 7 & 0,13 & 9 & 0,1 & $\mathbf{7 , 0}$ \\
\hline 7 & 5 & 0,12 & 7 & 0,1 & 6 & 0,3 & 1 & 0,25 & 1 & 0,13 & 6 & 0,1 & 4,1 \\
\hline 8 & 9 & 0,12 & 2 & 0,1 & 7 & 0,3 & 1 & 0,25 & 1 & 0,13 & 7 & 0,1 & 4,5 \\
\hline 9 & 6 & 0,12 & 2 & 0,1 & 1 & 0,3 & 5 & 0,25 & 5 & 0,13 & 1 & 0,1 & 3,2 \\
\hline 10 & 7 & 0,12 & 2 & 0,1 & 1 & 0,3 & 0 & 0,25 & 9 & 0,13 & 1 & 0,1 & 2,6 \\
\hline
\end{tabular}




\section{С. ЗІНЧЕНКО}

Індивідуальна траєкторія професійної адаптації студентів-військовослужбовців (учасників бойових дій) до продуктивної діяльності у сфері послуг

У табл. 2 наведено приклад комплексної оцінки множини професійних планів.

Відповідно до даних таблиці варіант № 6, для якого визначені такі оцінки відповідності:

$\mathrm{Q}_{1}=1 ; \mathrm{Q}_{2}=6 ; \mathrm{Q}_{3}=9 ; \mathrm{Q}_{4}=7 ; \mathrm{Q}_{5}=7 ; \mathrm{Q}_{6}=9$, «займає» перше місце з оцінкою 7,0 .

Використовуючи ці оцінки, можна розглядати варіанти для їхньої подальшої обробки (Садовський, Петренко, 2009).

Дослідники систематизували фактори професійної адаптації за групами:

- перша група факторів - внутрішні фактори професійної адаптації;

- друга група факторів - зовнішні адаптаційні фактори.

За теорією науковця-дослідника А. Уголєва всі фактори адаптаційного процесу поділяються на:

- стабільні, що незмінні впродовж довгого часу;

- змінні, що закономірно періодичні або не мають періодичності;

- фактори, що не викликають адаптацію (Философские проблемы теории адаптации, 1975).

Дослідники відзначають, що серед факторів адаптаційного періоду є успішність студента-військовослужбовця, його рівень здобутої освіти, рівень сформованих навчальних та організаційних умінь студента, рівень навчальної мотивації та навчально-виробничої практики.

Для перевірки впливу означених факторів на професійну адаптацію до продуктивної діяльності проведено експертне опитування студентіввійськовослужбовців щодо оцінювання вагомості факторів процесі адаптації.

1. Чому ви вирішили здобути вищу освіту рівня «бакалавр» («магістр»)?

a) є перспектива кар'єрного росту на роботі - 80 ч., $68 \%$;

б) вирішив змінити професію (профіль роботи) - 10 ч., $18 \%$;

в) на всякий випадок (стане в пригоді) - 24 ч., 20\%;

г) інше -5 ч., $4 \%$. 
Індивідуальна траєкторія професійної адаптації студентів-військовослужбовців (учасників бойових дій) до продуктивної діяльності у сфері послуг

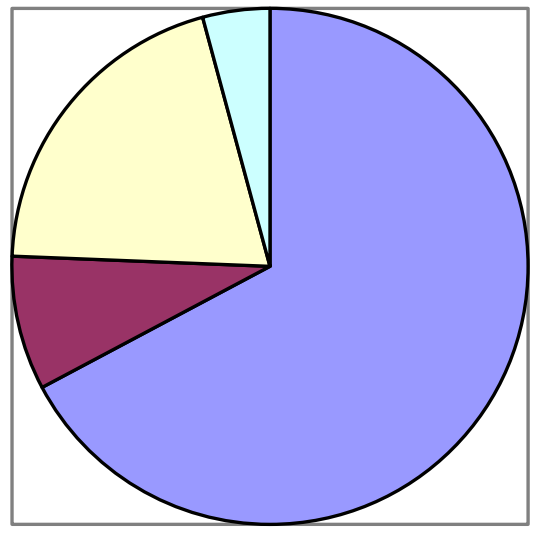

$$
\begin{aligned}
& \text { 口Перспектива } \\
& \text { кар'єрного росту } \\
& \text { 口Змінити професію } \\
& \text { वНа всякий випадок } \\
& \text { वlнше }
\end{aligned}
$$

Рис. 2. Оиінювання вагомості факторів

2. Що необхідно для покращення навчання?

a) збільшення кількості годин із вивчення навчальних дисциплін - 42 ч., $36 \%$;

б) забезпечення матеріальної бази, нове сучасне обладнанням - 75 ч., 64\%.
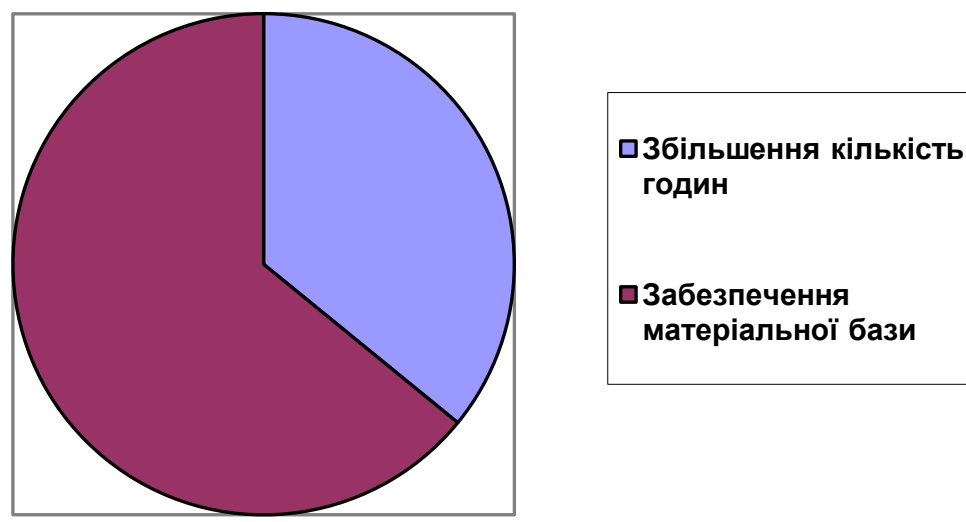

Рис. 3. Оиінювання вагомості факторів

До внутрішніх факторів професійної адаптації належать фактори, які визначають індивідуально-особистісні риси: стан здоров'я, мотивація вступу до навчального закладу, звички та риси характеру, тип нервової системи, громадська позиція, матеріальне забезпечення.

До зовнішніх факторів професійної адаптації належить соціальна поведінка, відношення в навчальній групі, мотивація надбання нових знань, умінь та навичок, стан матеріальної бази та навчально-методичного забезпечення навчального закладу, професіоналізм професорсько-викладацького складу, перспектива кар'єрного росту, престиж навчального закладу тощо.

Серед найбільш вагомих факторів в опитуванні є:

- перспектива кар'єрного росту на роботі - 68\%; 


\section{С. ЗІНЧЕНКО}

Індивідуальна траєкторія професійної адаптації студентів-військовослужбовців (учасників бойових дій) до продуктивної діяльності у сфері послуг

- престиж Нікопольського факультету НМетАУ (робота $з$ учасниками бойових дій) $-72 \%$;

- гарантоване працевлаштування - 67\%;

- забезпечення матеріальної бази (комп'ютерна зала, нове сучасне обладнання) $-64 \%$.

Можна зробити висновок, що процес професійної адаптації студентіввійськовослужбовців до продуктивної діяльності у сфері послуг відбувається під впливом факторів індивідуально-особистісних властивостей студентіввійськовослужбовців і специфічних особливостей навчального закладу.

У дослідженні професійної адаптації студентів-військовослужбовців до продуктивної діяльності у сфері послуг треба знати і враховувати всі труднощі процесу й умов, у яких вони перебувають.

Р. Якунін на основі своїх досліджень поділяє труднощі професійної адаптації на:

1) об'єктивні (велике навчальне навантаження, нові методи та форми навчання);

2) об'єктивно-суб’єктивні (слабка загальноосвітня підготовка, відсутність самоконтролю);

3) суб’єктивні (пропуск занять, випадковий вибір спеціальності, невміння подолати труднощі, відсутність навичок самостійної роботи) (Якунин, 1984).

П. Просецький на основі своїх досліджень поділяє труднощі на такі групи:

1) група пов'язана 3 особливостями психологічної саморегуляції та діяльності;

2) група пов'язана з організацією розумової праці;

3) група пов'язана зі зміною соціального оточення;

4) група пов'язана $з$ психологічною непідготовленістю студентів до оволодіння майбутньою професійною діяльністю (Просецкий, 1970).

За результатами тестування студентів-військовослужбовців виявлені такі труднощі:

a) слабкі знання загальноосвітніх дисциплін - 80 ч., $67 \%$;

б) посттравматичні наслідки (пам'ять, увага) - 30 ч., 25\%;

в) нестача часу для самостійної роботи - 9 ч., $8 \%$. 
Індивідуальна траєкторія професійної адаптації студентів-військовослужбовців (учасників бойових дій) до продуктивної діяльності у сфері послуг
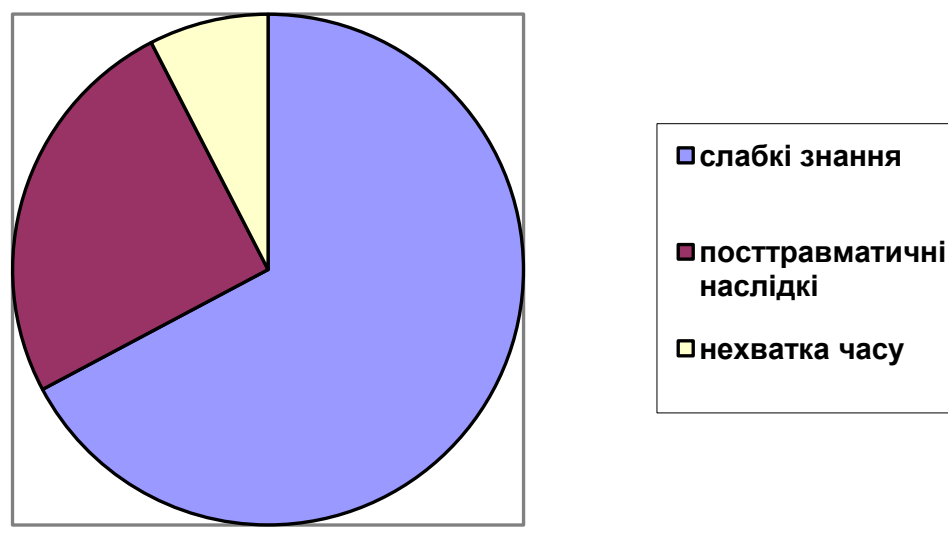

Рис. 4. Оиінювання вагомості труднощзів професійної адаптації

Розглянувши особливості професійної адаптації студентіввійськовослужбовців до продуктивної діяльності у сфері послуг, а також вивчивши фактори, що впливають на неї, можна вважати доцільним використання цього процесу у вищих навчальних закладах для покращання роботи зі студентами-учасниками бойових дій.

Для наукового дослідження професійної адаптації студентіввійськовослужбовців до продуктивної діяльності була використана така методика роботи.

Студенти-військовослужбовці повинні самостійно оцінити своє ставлення до різноманітних факторів, що впливають на продуктивну діяльність за п’ятибальною шкалою. Оцінку дають 12 факторам:

- взаємовідносини з однокурсниками, робота в команді;

- значимість професії;

- професійні знання і вміння;

- науково-дослідна робота;

- виробнича практика;

- перепідготовка, стажування, підвищення кваліфікації;

- організація праці;

- творчість у роботі;

- реалізація індивідуальних особливостей;

- фізично-психологічний стан;

- використання інтерактивних технологій;

- використання сучасних комп'ютерних програм.

Критерії оцінювання: 5 б. - дуже задоволений, 4 б. - задоволений, 3 б. посередньо задоволений, 2 б. - незадоволений, 1 б. - зовсім незадоволений. 
Індивідуальна траєкторія професійної адаптації студентів-військовослужбовців (учасників бойових дій) до продуктивної діяльності у сфері послуг

Таблиияя 3

Вплив факторів професійної адаптації до продуктивної діяльності

\begin{tabular}{|l|l|c|}
\hline \multicolumn{1}{|c|}{ Нo } & \multicolumn{1}{|c|}{ Назва фактора } & Вплив, \% \\
\hline 1 & Взаємовідносини з однокурсниками, робота в команді & 74 \\
\hline 2 & Значимість професії & 59 \\
\hline 3 & Професійні знання і вміння & 67 \\
\hline 4 & Науково-дослідна робота & 62 \\
\hline 5 & Виробнича практика & 77 \\
\hline 6 & Перепідготовка, стажування, підвищення кваліфікації & 60 \\
\hline 7 & Організація праці & 90 \\
\hline 8 & Творчість у роботі & 50 \\
\hline 9 & Реалізація індивідуальних особливостей & 73 \\
\hline 10 & Фізично-психологічний стан & 87 \\
\hline 11 & Використання інтерактивних технологій & 82 \\
\hline 12 & Використання сучасних комп’ютерних програм & \\
\hline
\end{tabular}

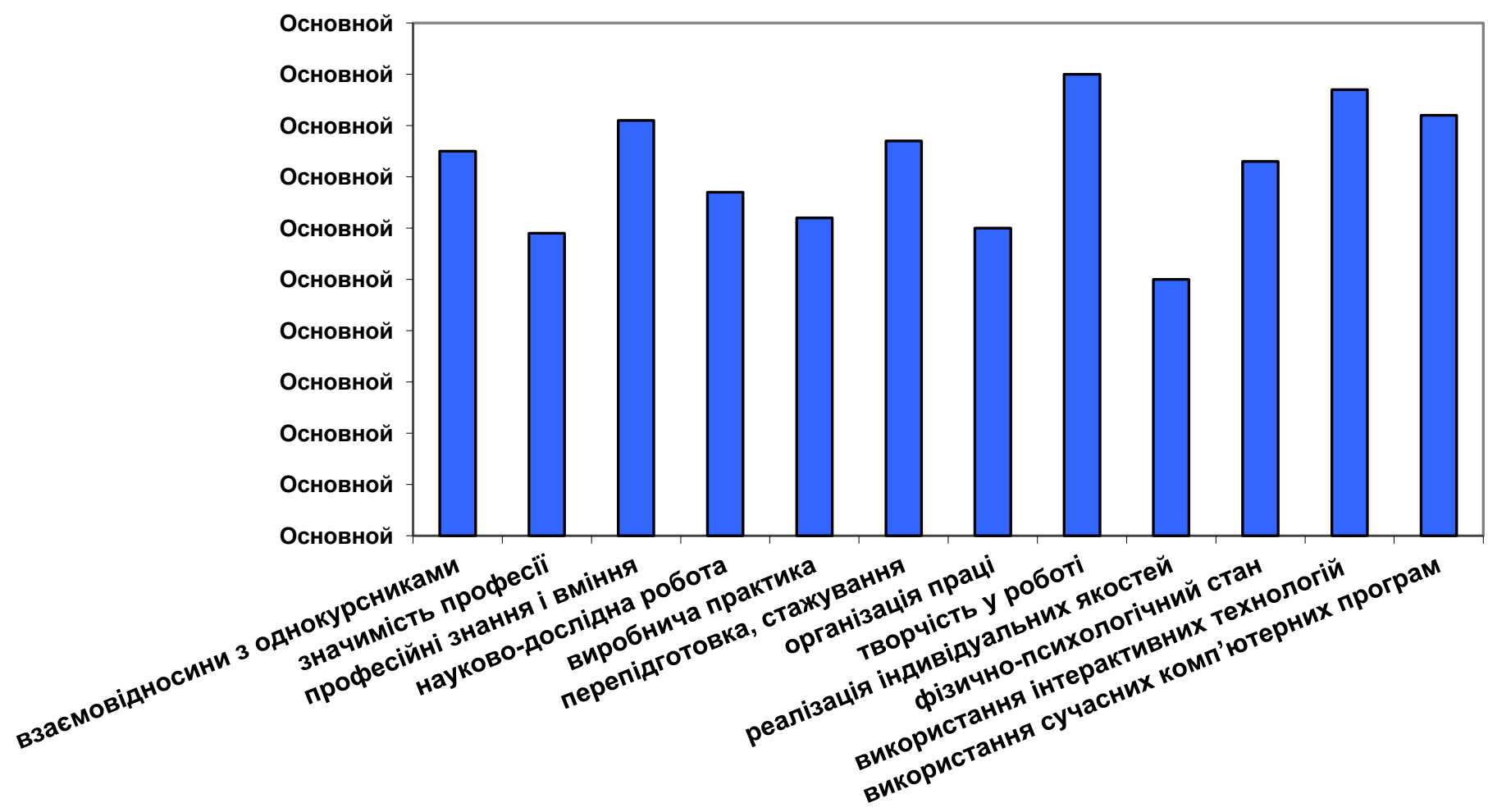

Рис. 5. Фактори професійної адаптац̧ії, які впливають на продуктивну діяльність

Виходячи 3 дослідження, можна зробити висновок, що найслабкіший фактор, який впливає на продуктивну діяльність, є реалізація індивідуальних 


\section{С. ЗІНЧЕНКО}

Індивідуальна траєкторія професійної адаптації студентів-військовослужбовців (учасників бойових дій) до продуктивної діяльності у сфері послуг

траєкторій розвитку особистості. А найсильнішими факторами є творчість у роботі, використання інтерактивних технологій, сучасних комп'ютерних програм.

Дослідження показало, що важливими факторами, які впливають на продуктивну діяльність є перепідготовка, стажування, підвищення кваліфікації, здібність працювати в команді, фізико-психологічний стан студентіввійськовослужбовців.

Індивідуальна траєкторія 3 професійної адаптації студентавійськовослужбовця корисна як для студента-військовослужбовця, так і для роботодавців. Результат реалізації цих заходів, як показує дослідження, $\epsilon$ великою потребою для мотивації продуктивності діяльності у сфері послуг.

Висновки. Відповідно до наявних методик і програм були розглянуті індивідуальні траєкторії професійної адаптації студентів-військовослужбовців (учасників бойових дій) до продуктивної діяльності у сфері послуг. Індивідуальна освітня траєкторія - це рух до досягнення рівня професійної компетентності, що здійснюється за постійної педагогічної підтримки i контролю, у процесі якого відбувається творча самореалізація, прояв і розвиток особистісних якостей. Індивідуальний освітній маршрут - це персональна програма для ефективної професійної адаптації підготовки фахівця, що відповідає його віку і здібностям, інтересам, мотивації, яка спроєктована на базі освітньо-професійної програми. Студент-військовослужбовець (учасників бойових дій) зможе просуватися по індивідуальній траєкторії професійної адаптації за умов, якщо йому будуть надані можливості: вибирати оптимальні форми і темпи навчання; застосовувати ті способи навчання, які найбільш відповідають його індивідуальним особливостям; рефлексивно усвідомлювати отримані результати, здійснювати оцінку і коригування своєї продуктивної діяльності.

Подальшу роботу ми вбачаємо в розробці моделі професійної адаптації студентів-військовослужбовців (учасників бойових дій) до продуктивної діяльності у сфері послуг.

\section{СПИСОК ВИКОРИСТАНИХ ДЖЕРЕЛ}

1. Байбекова, Л. О. (2016). Педагогічні умови адаптації майбутніх філологів до професійної діяльності. Збірник наукових пращь «Педагогіка та психологія», 55, 117-128.

2. Вудкок, М., Френсис, Д. (1991). Раскрепощенный менеджер. (A practical guide to selfdevelopment). Москва, Российская Федерация: Дело.

3. Гайдеггер Мартин. (1997). Бытие u время.В.В.Бибихина (пер.). Москва, Российская Федерация: Ad Marginem.

4. Мороз, А. Г. (1984). Профессиональная адаптаичия выпускников педагогического ВУЗа. (Дис. д-ра пед. наук). Киев, Украина.

Професіоналізм педагога: теоретичні й методичні аспекти. - Вип. 12. - Слов’янськ, 2020. 


\title{
С. ЗІНЧЕНКО
}

Індивідуальна траєкторія професійної адаптації студентів-військовослужбовців (учасників бойових дій) до продуктивної діяльності у сфері послуг

5. Полянская, Е. В. (2013). Кадровое планирование на государственной службе: сборник. Стратегия устойчивого развития: актуальные вопросы и тенденции / Байсултанова Д. А., Шевченко Е. А. Москва, Российская Федерация.

6. Просецкий, П. А. (1970). Социально-психологические аспекты адаптации воспитанников средней школы к условиям вузовского коллектива. Известия ВГПИ, 14-20.

7. Ростова, Л. М. (1973). Социальная адаптация личности в коллективе. (Автореф. дис. канд. пед. наук). Томск, Российская Федерация.

8. Садовський, А. В., Петренко, А. Л., Шатоха, В. И. (2009). Управление профессиональной карьеры. Днепропетровск, Украина: Пороги.

9. Семенова, А. В. (Ред.-упоряд.). (2006). Словник-довідник з професійної педагогіки. Одеса, Україна: Пальміра.

10. Царегородский, Г. И. (Ред.). (1975). Философские проблемы теории адаптации. Москва, Российская Федерация: Мысль, 1975.

11. Якунин, Р. Ф. (1984). Социильно-педагогические аспекты адаптациии латиноамериканских студентов к условиям советского вуза (на примере университета Дружбы народов им. П. Лумумба). (Дис. канд. пед. наук). Москва, Российская Федерация.

12. Savchenko, L. (2018). Functional role of monitoring in assessing the quality of future handicraft teacher training. Science and education, 2, 186-192. DOI: https://doi.org/10.24195/2414$\underline{4665-2018-2-25}$

\section{INDIVIDUAL TRAJECTORY OF PROFESSIONAL ADAPTATION OF STUDENTS-MILITARY PERSONNEL (PARTICIPANTS OF MILITARY ACTIONS) TO PRODUCTIVE ACTIVITY}

\author{
Svitlana Zinchenko \\ Director of the Nikopol Regional Center of \\ Monitoring Education and Social Partnership \\ ORCID ID 0000-0003-1242-2414 \\ svzi@ukr.net
}

\begin{abstract}
The article theoretically substantiates, investigates, determines the individual trajectory that contributes to the optimization and effectiveness of professional adaptation of military students to productive activities in the field of services; to develop and experimentally test the method of formation of professional adaptation of military students to productive activity in the sphere of services. The issue is considered to be relevant as one of the essential factors of improving professional and social-psychological adaptation of students-military personnel to productive activities is ensured through the implementation of interactive learning methods and modern computer technologies into learning process, taking into consideration the pedagogical conditions of adaptation. The concept of "individual trajectory", "individual route" of professional adaptation of students-military personnel (participants of military operations) is defined. Criteria for professional adaptation of military students are developed. Individual educational trajectory is a movement towards achievement, a level of professional competence, which is carried out with constant pedagogical support and control, in the process of which there is a creative self-realization, manifestation and development of personal qualities, respectively. Individual education route is a personal program for effective professional adaptation of specialist training, corresponding to his/her age and abilities, interests, and motivation, which is designed on the basis of educational and professional program. Student- military personnel (participants of military operations) are able to advance on the individual trajectory of professional adaptation if they are given the following
\end{abstract}

(ㄷ ДВНЗ «Донбаський державний педагогічний університет» 


\section{С. ЗІНЧЕНКО}

Індивідуальна траєкторія професійної адаптації студентів-військовослужбовців (учасників бойових дій) до продуктивної діяльності у сфері послуг

opportunities: to choose the optimal forms and rates of training; apply those learning methods that best correspond to his or her individual characteristics; to reflect on the results obtained, to evaluate and adjust their productive activities.

Key words: professional adaptation; productive activity; interactive technologies; studentsmilitary personnel; individual trajectory.

\section{REFERENCES}

1. Baibekova, L. O. (2006). Pedagogical conditions of adaptation of future philologists to professional activity. Zbirnyk naukovykh prats "Pedahohika ta psykholohiia", 55, 117-128.

2. Woodcock, M., Francis, D. (1991). Relentless manager. (A practical guide to selfdevelopment). Moscow, the Russian Federation: Delo.

3. Heidegger, M. (1997). Being and Time. V. V. Bibikhin (Tr.). Moscow, the Russian Federation: Ad Marginem.

4. Moroz, A. G. (1984). Professional adaptation of graduates of pedagogical university. (PhD Dissertation). Kyiv.

5. Polyanskaya, E. V. (2013). Personnel planning in the civil service: a compilation. Sustainable development strategy: current issues and trends. Moscow, the Russian Federation.

6. Prosetskiy, P. A (1970). Socio-psychological aspects of the adaptation of high school students to the conditions of the university collective. Izvestiya VGPI, 14-20.

7. Rostova, L. M. (1973). Social adaptation of the individual in the team. (Extended abstract of PhD dissertation). Tomsk, the Russian Federation.

8. Sadovskiy, A. V., Petrenko, A. L., \& Shatoha, V. I. (2009). Professional Career Management. Dnepropetrovsk, Ukraine: Porogi.

9. Semenova, A. V. (Ed.). (2006). Dictionary-reference book on professional pedagogy. Odesa, Ukraine: Palmyra.

10. Tsaregorodskiy, G. I. (Ed.). (1975). Philosophical problems of adaptation theory. Moscow, the Russian Federation: Mysl.

11. Yakunin, R. F. (1984). Socio-pedagogical aspects of the adaptation of Latin American students to the conditions of the Soviet university. (PhD Dissertation). Moscow, the Russian Federation.

12. Savchenko, L. (2018). Functional role of monitoring in assessing the quality of future handicraft teacher training. Science and education, 2, 186-192. DOI: https://doi.org/10.24195/2414$\underline{4665-2018-2-25}$

Матеріали надійшли до редакції 26.12.2019 р. 